\title{
Workplace Monitoring and Surveillance: The British Context
}

\author{
By Graeme Lockwood ${ }^{*}$
}

\begin{abstract}
This paper reviews the monitoring of employees by their organisations across a variety of sectors and industries in British workplaces. The contribution of the paper is to approach empirically the reasons that employers give for engaging in monitoring and how employees assess the practice. Valuable distinctions are raised in terms of different employee attitudes to surveillance within and outside the workplace. The findings are derived from interviews with human resource managers, managers, trade union representatives, employers and employees.
\end{abstract}

Keywords: Employment Law; employment relations; monitoring; surveillance; workplace privacy;

\section{Introduction}

This article explores the views of employers and employees in British workplaces concerning monitoring in the workplace and determines the effect of such activity on those exposed to it and the implications for the employment relationship. Evaluation and scrutiny of employee behaviour, conduct, and performance are a common occurrence in many organisation contexts. Indeed, there has been increasing concern about the nature and scope of surveillance at work. ${ }^{1}$ A significant number of employers engage in employee monitoring of various forms. Research in the USA has revealed that surveillance in the workplace is common practice with it being deployed by nearly eighty per cent of employers. ${ }^{2}$ In the UK context, it is estimated that sixty per cent of employers engage in monitoring of employees. ${ }^{3}$ In the UK, a growing trend has seen social media being implicated in dismissals in the workplace. This degree of management control over the workplace has added a new dimension to the employer and employee relationship. ${ }^{4}$ The ability to monitor and exert control over employees in a variety of different ways increases managerial prerogative. In the context of increased monitoring by employers and developments in the law relating to workplace privacy it is appropriate to review the situation with regard to workplace monitoring.

There are a variety of reasons that an employer might wish to monitor the

${ }^{*} \mathrm{PhD}$; Senior Lecturer in Business Law and Employment Relations, King's Business School, King's College London, University of London, UK. Email: graeme.lockwood@kcl.ac.uk.

${ }^{1}$ Lee \& Kleiner (2003); Mello (2003); National Workplace Institute (2004); D’Urso (2006); Barry, Fiedman \& Reed (2007).

${ }^{2}$ Esen (2005); D’Urso (2006).

${ }^{3}$ Waugh (2012).

${ }^{4}$ Nord, McCubbins \& Nord (2006). 
activities of their staff: on security grounds; health and safety; performance management; protecting organisational resources and interests and compliance with legal and regulatory requirements. Advances in computer technology have increased the employer's ability to monitor the electronic communications of employees in the workplace. ${ }^{5}$ Employers monitor a variety of employee activities in the workplace including: email; telephone calls; Internet use and computer files.

In the UK context, the risk of legal action from inappropriate email use by employees has been evident since Norwich Union had to pay Western Provident (WPA) $£ 450,000$ after defamatory emails were circulated by Norwich Union staff. ${ }^{6}$ Such cases resulted in employers increasingly monitoring their employees' email to prevent their own potential liability stemming from employees' misuse of email while at the workplace. ${ }^{7}$ It is also pertinent to monitor employee communications in order to protect staff from distressing or harassing behaviour that could distress colleagues, potentially affecting their performance; see for example, Garamukanwav Solent NHS Trust [2016].

\section{Literature on Monitoring \& Surveillance}

Sewell, Barker and Nyberg ${ }^{8}$ identified that employees could perceive monitoring activity of an employer in one of two ways. On the one hand, employees could view workplace surveillance as an impartial tool used by managers to promote individual and organisational effectiveness. Alternatively, it could be considered an instrument of oppression that subordinates the interests of workers to those of their employers'.

Foucalt ${ }^{9}$ discusses the concept of "panoptic power", the ability to see all, in organisations. The Panopticon on concept originated with Jeremy Bentham's thoughts about managing eighteenth-century total institutions such as prisons and asylums. ${ }^{10}$ Control in these organisations was maintained by subjecting the inmates to the possibility of their behaviour being observed by those in authority at any given time and without their knowledge. ${ }^{11}$ Botan ${ }^{12}$ referring to this in a modern context observes that increases in surveillance, whether they are expected or accepted, can result in panoptic effects, the degree to which individual employees feel they are controlled through various communication technologies. However, Findlay and McKinlay ${ }^{13}$ contend that legal constraints significantly affect employer choices about how surveillance actually operates and that, in practice, worker monitoring seldom achieves the extent, depth or continuity portrayed by 'panopticism'.

\footnotetext{
${ }^{5}$ King (2003).

${ }^{6}$ Practical Law (1997).

${ }^{7}$ Barry, Fiedman \& Reed (2007).

${ }^{8}$ Sewell, Barker \& Nyberg (2011) at 189.

${ }^{9}$ Focault (1979).

${ }^{10}$ Brown (2000) at 63.

${ }^{11}$ Brown (2000) at 63.

${ }^{12}$ Botan (1996).

${ }^{13}$ Findlay \&McKinlay(2003) at 305.
} 
Oliver $^{14}$ asserts that having a right to privacy is important to maintain a person's autonomy, dignity and personal wellbeing, and further that privacyinvasive practices may inhibit independence of thought and creativity, as people are not able to think properly if they know or think that they are being watched. Oliver also observes that "there is [...] substantial evidence that privacy-invasive practices in the workplace, particularly pervasive surveillance, can cause actual psychological damage and stress related illness" ${ }^{15}$. Taylor and Emir ${ }^{16}$ raise the issue of whether there is a sphere of privacy that surrounds the employee that cannot be taken away, or whether employers are within their rights to monitor their employees' activities and correspondence. Friedman and Read ${ }^{17}$ assert that when citizens take on the role of employees, their right to privacy is increasingly subjugated to employers' interests.

Whilst employers have a variety of legitimate grounds for engaging in monitoring in the workplace an employer needs to be sensitive to the industrial relations implications of monitoring. Employees might argue that surveillance infringes on the right of privacy, infringes on their human dignity, decreases employee loyalty, increases stress, anxiety and anger, lowers productivity and negatively affects job satisfaction. ${ }^{18}$

The purpose of this study is to explore the attitudes of employers and employees regarding workplace privacy in order to explore the boundaries of appropriate monitoring in the workplace context. Next, the legal framework is outlined.

\section{The Legal Framework}

The role of the law is to strike an appropriate balance between the legitimate interests of employers to protect business assets, against the need to protect the privacy of workers. Employers should be transparent about the nature and content of monitoring, and should have social media, Internet and email policies in place. ${ }^{19}$ Ford $^{20}$ observes that the common law gave "almost absolute priority to management prerogative and almost no recognition to workers' private interests." However, monitoring policies can give rise to a number of difficult legal and employee relation's issues. If an employer does not handle these difficulties appropriately, it can lead to disgruntled employees, damaged organisational loyalty and legal challenges. For example, if an employee believes that the monitoring policy is oppressive or introduced unilaterally it might give rise to an action for breach of contract. It would need to be established that the employer

\footnotetext{
${ }^{14}$ Oliver (2002).

${ }^{15}$ Oliver (2002) at 325.

${ }^{16}$ Taylor \& Emir (2015) at 430.

${ }^{17}$ Barry, Fiedman \& Read (2007) at 76.

${ }^{18}$ Smith, Carayon, Sanders, Lim \& LeGrande (1992); Levy (1994); Lee \& Kleiner (2003); Barry, Fiedman \& Reed (2007).

${ }^{19}$ Phillips \& Scott (2016) at 428.

${ }^{20}$ Ford (2002) at 148.
} 
action constituted a breach of the implied duty of mutual trust and confidence. ${ }^{21}$ Furthermore, if an employee with two years' continuous service was dismissed as a result of unreasonable monitoring the employer might face an unfair dismissal claim. An employer should carefully consider the legal issues involved when introducing a monitoring policy to avoid unreasonable and unnecessary restrictions on the workforce. However, to date, the UK common law has taken a conservative approach, largely upholding the right of management to decide what level of monitoring is necessary and appropriate.

Due to the limitations of challenging management monitoring practice through the contract of employment, there is now a myriad of legal provisions that are relevant to the issue of monitoring in the workplace. This includes; Human Rights Act, 1998; Data Protection Act, 1998 supplemented by the Employment Practices Data Protection Code, 2011; the Regulation of Investigatory Powers Act, 2000 and the Telecommunications (Lawful Business Practice) (Interception of Communications) Regulations, 2000, and the Equality Act, 2010.

In respect to the Human Rights Act 1998, section 3(1) provides, so far as it is possible to do so, primary legislation and subordinate legislation must be read and given effect in a way which is compatible with the European Convention on Human Rights 1950. The provision of the Human Rights Act, 1998 most relevant to monitoring policies is Article 8 which gives a right to respect for private and family life, home and correspondence. In the employment arena, Article 8 in particular is used to protect employees' privacy. It may allow employees to challenge over-intrusive policies by employers. For example, if the employer intercepts calls from a separate work telephone provided to the employee for private use, the employee may be able to bring a claim under Article $8 .^{22}$ If the worker is a public sector employee, he/she may have a freestanding claim under Article 8. If the worker is a private sector employee, he/she may be able to rely indirectly on Article 8 in an unfair dismissal or breach of contract context. ${ }^{23}$ In a recent case - Babulescu v. Romania ${ }^{24}$, the employer prohibited workers' use of equipment for private purposes. The employer detected infringement of the rule by monitoring the employees Yahoo Messenger communications, which included personal communications. The employee sued his employer for an infringement of Article 8 privacy and brought his complaint to the ECHR. The ECHR concluded that on the evidence the monitoring by the employer was proportionate and legitimate in the circumstances. The ECHR rejected the claim, on the ground that the employer was only attempting to prevent a breach of work rules and the employee was in breach of his contract of employment. The development of the law relating to privacy under the HRA continues to develop slowly and in a limited direction. It has not resulted in major restrictions being placed on employers in terms of monitoring of employees.

The European Union issued the Data Protection Directive 95/46/EU in October 1995 that concerned the processing of personal data and the free

\footnotetext{
${ }^{21}$ United Bank $v$ Akhtar [1989].

${ }^{22}$ Halford v UK [1997].

${ }^{23}$ Phillips \& Scott (2016) at 425.

${ }^{24}$ Babulescu v. Romania [2016] ECHR.
} 
movement of such data. The Data Protection Act 1998 was introduced to implement this directive into UK law. In accordance with the Data Protection Act, 1998 (DPA) employers must process their employees' data in a fair, proper and lawful manner. Protection covers both computer-processed personal data, if the data were retrieved "by reference to an employee", and paper-based personal records stored in filing systems "by reference to employees or criteria relating to them" $" 25$. The DPA also covers monitoring at work and the information commissioner has issued under section 51 of the DPA 1998 the Employment Practices Data Protection Code, 2011. Whilst the code is not legally binding it may be relied upon in any proceedings alleging a breach of the DPA. The information commissioner suggests that before monitoring is undertaken an impact assessment should be completed and whether monitoring is reasonable and proportionate will depend on such issues as the purpose of the monitoring, the likely adverse effect of the monitoring, whether there are any alternatives which will achieve the same objectives, what obligations monitoring creates, and whether on balance, the monitoring is justified. Interestingly, the code raises the question as to whether employees must consent to the monitoring and identifies problems with the notion of consent in the employment relationship. The code states:

There are limitations as to how far consent can be relied on in the employment context to justify the processing of personal information. To be valid, for the purposes of the Data Protection Act, consent must be "freely given", which may not be the case in the employment environment. Once given, consent can be withdrawn. In any case, employers who can justify monitoring on the basis of an impact assessment will not generally need the consent of individual workers. ${ }^{26}$

In relation to covert monitoring, paragraph 3.41 of the code provides that covert monitoring should not normally be undertaken and should only be used where criminal activity or equivalent malpractice is suspected.

A further addition to the legal patchwork came in the form of the Regulation of Investigatory Powers Act, 2000. The regulations permit an employer to intercept communications with consent (from both parties to the communication) only if it complies with the provisions of the Telecommunications (Lawful Business Practice) [Interception of Communications Regulations 2000(SI 2000/2699]. The regulations create a number of 'lawful purposes' whereby employers can monitor and record communications between parties with their consent, or where the employer believes they have consented. These lawful purposes include: creating records in case a dispute arises; ensuring compliance with regulatory or statutory rules; ascertaining or demonstrating employee standards; customer care; prevention of crime and security against hackers; investigating the unauthorised use of the telecommunications system. The regulations have been

\footnotetext{
${ }^{25}$ Durant v Financial Services Authority [2004].

${ }^{26}$ Employment Practices Data Protection Code (2011) at 63.
} 
subject to considerable criticism, it has been observed that the regulations hardly limit employer monitoring practices at all, they place business interests above privacy and fail to police the use of collateral personal information. ${ }^{27}$

Finally, the employer's monitoring and surveillance practices must not contravene prohibited discrimination in respect of the following protected characteristics listed in s.4 of the Equality Act 2010: age (s5); disability (s6); gender reassignment (s7); race (s9); religion or belief (s10); sex (s11); or sexual orientation (s12).

\section{Methodology}

The research was conducted in four phases. First, a literature review was undertaken that examined scholarly work on monitoring and privacy in the workplace. Second, an analysis of relevant legal cases was undertaken. The population of individual case records with a privacy component was accessed electronically from a variety of legal databases. The cases raised important legal data relating to the application of monitoring practices by employers. The cases examined both first instance and appellate decisions. Next, an extensive document search was conducted that yielded a large number of employer policies relating to monitoring, especially in care homes and call centres.

Finally, semi-structured interviews were conducted with a sample of respondents. The interviews typically lasted 45 minutes and each respondent is reported on an anonymous basis but provided with an identifier to highlight their role. The research, based on 50 interviews with HR specialists, line managers; trade union officials and employees, was conducted between July and December 2016. The participants were recruited through a snowball sampling method. Semi-structured interviews were conducted at locations that were convenient to the participants, usually away from the workplace. The flexibility offered by semi-structured interviews ${ }^{28}$ allowed for an in-depth exploration of the workers' feelings and attitudes. The respondents were informed that the aim of the study was to understand a variety of work-related experiences of monitoring in the workplace. They were assured that their participation would be strictly anonymous and that the conversations would be treated with confidentiality. An interview guide was developed to cover similar issues with all the participants. This provided for a systematic and comprehensive mode of enquiry. ${ }^{29}$ The guide consisted of questions relating to participants' experiences of monitoring in the workplace.

\section{Research Findings}

The findings in this paper are divided into three main categories: (i) employer

\footnotetext{
${ }^{27}$ Oliver (2002) at 339; Findlay \& McKinlay (2003) at 309.

${ }^{28}$ King (2004); Nath (2011).

${ }^{29}$ Patton (1990) at 283; Nath (2011) at 713.
} 
reasons for monitoring in organisations; (ii) Employees views on monitoring and how employees are informed of monitoring; and (iii) employment relations issues.

\section{(i) Reasons for monitoring in organisations}

\section{a) Protecting Organisational Resources}

The majority of employer respondents in the study stressed the significance of protecting the assets and resources of their firm through monitoring. Protection of intellectual property rights was advanced as a significant justification for monitoring in a number of industries. A security manager at a financial firm observed:

It is common and relatively straightforward for workers to abuse the use of company property and assets so monitoring is not unreasonable, in fact, the failure to do so would constitute poor management.

Many managers viewed it as the employer's right to monitor their employees' use of the company's business systems on the ground that it was reasonable to ensure that work was being performed to an appropriate standard. In particular, employers are often keen to determine that systems are utilised for relevant business purposes and to safeguard that only appropriate material is conveyed via information systems. The following interviewee felt that the employer needed to be sensitive in terms of the work rules imposedon employees, particularly in respect to email and Internet use:

The Internet in the workplace is an important tool at the employee's disposal. In my view it is not practical for an employer to place a blanket ban on the use of the Internet for private purposes. However, it is necessary for an employer to make checks because employees could damage the company's IT systems, engage in illicit activities in the company's name, or reveal the company's commercial secrets. (Manager)

Respondents often emphasised that an employer needed a balanced approach to the use of business property by employees.

In my view, it's unreasonable not to allow employees to make or receive some private phone calls. As for the Internet, we prohibit the sending and receiving of personal emails at work. Web browsing is fine at break times. We prohibit online gambling and the downloading of pornography. (Manager, Insurance firm)

Company policy is that staff can send and receive emails occasionally as long as the messages are not offensive or damaging to the company. We did have one employee who seemed to be using the email on a regular basis and talking in hushed tones on the phone. It was odd because we do not 
need to send a lot of business emails. I challenged him as his line manager and it transpired that he was running a part-time business from the office. He was taken through the disciplinary procedure and dismissed. If I had not monitored his behaviour this could have gone on for sometime which could have been damaging to the business. (Line Manager)

However, there was concern expressed by a few respondents about their organisation's failure to disclose to employees that monitoring was taking place and questions were raised as to the legality of some monitoring.

When we first started monitoring there was no policy in force and employees were not told. However, this has changed, now a policy is in place and employees are informed of the company practice. I also know that the firm has engaged in covert surveillance of one employee, tracking their personal movements when at work, on annual leave and sick leave. I am sure this infringed the law. Some members of staff have expressed the view that some of the monitoring is inappropriate and intrusive. (Manager Hi-Tech Firm)

It was also evident that some managers knew that the monitoring undertaken by their organisation could be perceived as demonstrating a lack of trust in the workforce and that it had a negative effect on employees' attitude to the workplace. Monitoring made staff feel uncomfortable and it was regarded as undermining good employment relations.

\section{(b) To Protect the Employer from Legal Claims}

Another reason for employee monitoring during the interviews was that employers needed to take reasonable steps to ensure they did not face legal claims of harassment or discrimination. Harassment, bullying and abusive behaviour are a common occurrence in many organisation settings and it is important for an employer to guard against such situations. ${ }^{30}$ Hunt et al. ${ }^{31}$ observe that if management allows a climate of disrespect to exist within an organisation, this makes it more likely for certain inappropriate behaviour to be taken for granted, and leads to the creation of an 'incivility spiral'. If employees send, inappropriate emails or post derogatory remarks on the company web page the employer could be vicariously liable for any discriminatory conduct. ${ }^{32}$ Employers expressed growing concern about the possibility of legal actions arising from employees sending inappropriate material or sensitive data using business information technology systems. It is therefore, sensible for employers to take measures to protect themselves against such incidents. For example, in one case two coworkers posted remarks on a colleague's Facebook page relating to his sexual orientation. The incident happened during the course of employment and the conduct related to the relationship between staff and a manager. As the events

\footnotetext{
${ }^{30}$ Deery, Walsh \& Guest (2011).

${ }^{31}$ Hunt, Davidson, Fielded \& Hoel (2007).

${ }^{32}$ Equality Act, 2010.
} 
occurred in work time the employer was held vicariously liable for the conduct, which constituted harassment on the grounds of sexual orientation. ${ }^{33}$ In Teggart v. Tele Tech Ltd UK $L t d^{34}$ the employer was held to have fairly dismissed an employee for posting offensive remarks about a work colleague on his Facebook page. The employment tribunal held that when the employee made the remarks on Facebook they were placed in the public domain and he could not invoke Article 8 regarding respect for private life to argue that the dismissal was unfair.

However, some of the monitoring in this domain was also designed to protect staff, for example, to detect hostile abuse or discrimination of staff by customers. Interviews revealed a widespread prevalence for frontline service workers to be subject to such hostility and bullying treatment. It is well established that victims of customer-instigated verbal abuse can experience high levels of stress and depression $^{35}$, emotional dissonance and burnout. ${ }^{36}$

It is evident that both to protect themselves from legal action and to protect employees from abuse it is fair and sensible for an employer to monitor the use of social media and IT devices in this respect. Cambridge University research (2016) has revealed that police body cameras have reduced complaints by ninety-threeper cent over 12 months compared with the year before. ${ }^{37}$ The study included around 2,000 officers across four UK forces and two US police departments. Dr Barak Ariel, who led the research stated:

I cannot think of any other single intervention in the history of policing that dramatically changed the way officers behave, the way that suspects behave, and the way they interact with each other. The results indicate that both police and the public were adjusting their behaviour. Once the public is aware they are being recorded, once they know that everything they do is caught on tape, they will undoubtedly change their behaviour because they don't want to get into trouble. Individual officers become more accountable, and modify their behaviour accordingly, while the more disingenuous complaints from the public fall by the wayside once the footage is likely to reveal them as frivolous. ${ }^{38}$

\section{(c) Health and Safety}

Six respondents in the sample justified monitoring for safety reasons. An interviewee in the commercial construction sector explained that health and safety monitoring was essential to maintain an efficient, safe and legally compliant work environment. Worker behaviour and the wearing of appropriate protective clothing were monitored routinely, for example, to ensure the wearing of highvisibility jackets, hard hats and boots. This was seen to encourage the safety

\footnotetext{
${ }^{33}$ Otomewo v Carphone Warehouse Ltd [2012).

${ }^{34}$ Teggart $\mathrm{v}$ Tele Tech Ltd UK Ltd [2012]

${ }^{35}$ Boyd ( 2002); Yagil (2008),

${ }^{36}$ Grandey, Dickter \& Sin (2004).

${ }^{37}$ Coleman (2016). Shaw (2016).

${ }^{38}$ Ariel (2016),
} 
culture of employees and thereby enhance the safety climate of the organisation.

It is important to monitor that staff act appropriately on the site, wear acceptable clothing and use the safety equipment provided - you have to be equipped to do that job in a safe fashion. If the firm breaches the law significant financial penalties and reputational damage is likely to be the outcome. (Senior Health and Safety Manager, Construction)

\section{(d) Employee Screening}

The study identified that pre-employment screening is a growing dimension in monitoring practice. It was considered important for some employers to check the accuracy of candidate information, for example, previous employment, credit history, criminal records, and to identify changes in circumstances that could pose a risk to the organisation. The following quote is illustrative:

It is becoming common practice to rescreen employees, or a random selection of employees, annually as well as on promotion or a change of responsibilities. [HR Manager]

Another aspect relating to employee screening raised by several respondents, both employers and employees, related to drug and alcohol testing. One manager in an estate agency commented:

I strongly support the idea that employers should have the legal right to test all workers for drug or alcohol if they wish irrespective of their occupation. In fact I think it should be done every Monday morning. It relates not just to health and safety issues but also directly to the quality of work performance.

Overall, employers strongly supported drug testing while employees' opinions were mixed. Interestingly it did appear to be an issue of increasing concern and debate.

Another controversial aspect of employee screening concerned the manner in which recruitment decisions were made. In particular, it has been suggested that the increased use of employers making reference to individual social networking sites could result in recruitment decisions that are rooted on discriminatory grounds. The Equality Act 2010 protects workers from discrimination on grounds of race, age, gender, disabilities and religion. Such information can be easily ascertained from social networking sites and there is a genuine risk that employers might infringe the equality rules. ${ }^{39}$

A final issue of concern raised by the research in relation to employment screening was an admission by several respondents that they looked negatively on candidates who did not have a social network profile. The likelihood is that social media usage might differ on age, ethnicity and personality, resulting in unfair treatment. There is a real danger that unchecked employer screening of

\footnotetext{
${ }^{39}$ Thomas, Rothchild \& Donegan (2014); Jeske \& Shultz (2016).
} 
social media will result in a breach of privacy by infringing on dignity and personal wellbeing. In this domain employers seem to be undervaluing employees right to privacy and ignoring the evidence that recruitment decisions based on social media can result in discriminatory and poor recruitment decisions. ${ }^{40}$ Social media monitoring enables employers to glean information on the views and interests of potential candidates that were not previously available to employers in the recruitment and selection process.

\section{(e) Monitoring Work Performance}

Employers often conveyed the belief that it was important to monitor staff in order to ensure: appropriate levels of productivity, work quality, appropriate behaviour, deliver appropriate levels of service and to prevent workers wasting time.

We had one employee who was subject to disciplinary action for spending hours of work time searching the Internet for cheap weekend breaks. Monitoring software enabled us to show exactly how much work time had been taken up with this activity. (HR Manager Insurance Company)

In respect of measuring work performance, the research revealed some extensive and interesting monitoring practices in three particular settings these included, care homes, call-centres and professional sports clubs.

\section{Care Homes}

Monitoring in care homes was strongly advocated due to a history of wellpublicised systemic failures and abuse of patients by staff. ${ }^{41}$ The interviews undertaken for this study revealed agreement amongst different stakeholders, including industry representatives, employees and clients, about the need and value of monitoring in care home establishments.

I am the owner of a care home and I have had CCTV cameras in my communal areas, corridors, kitchens and outside the grounds for several years. There is no infringement on human rights as it is not watched continuously. It is only viewed by two members of staff and relatives if required. (Care Home Owner)

CCTV is a must in a care home. My nan suffered terrible physical, verbal and mental abuse as well as daily bad care. Without CCTV we would not have caught my Nan's abuser! (Client)

I have often heard people say that CCTV cannot be used in care homes, as it is an 'invasion of personal privacy', when in fact it is over-looked that the Human Rights Act 1998 provides for a right to private life without

\footnotetext{
${ }^{40}$ Brown \& Vaughn (2011); Jeske \& Shultz (2016); Van Iddekinge, Lanivich, Roth \& Junco (2016); Timming (2015).

${ }^{41}$ Social Care Institute for Excellence (2014).
} 
unnecessary interference from the State. This right of a 'private life' includes the absolute right not to be assaulted, abused or neglected. The overriding principle when it comes to interpreting the Human Rights Act: 'Is the action being taken or contemplated necessary, reasonable and proportional. I believe that the answer to all three of these questions is a resounding 'yes' and the sooner CCTV is introduced into all care homes, the safer those in care homes will become (Family Law Solicitor)

However, in respect to monitoring in the care home setting it is interesting to note that Niemeijer et al systematic review of surveillance technologies in residential care for people with dementia or intellectual disabilities noted that 'the effects of this technology [...] have scarcely been studied' ${ }^{42}$, and Woolrych et al. highlights the lack of before-and-after comparative analysis ${ }^{43}$.

\section{Call Centres}

Weaknesses in employee relations and the management approach to monitoring were brought into the spotlight by interviews with employees in call centres. Several respondents explained how staff were evaluated on their average handling time (AHT) and if employees failed to meet the specified AHT they would face performance management. This could involve anything from stern words, warnings and dismissal. The following quotes illustrate the negative feelings of call centre staff towards the management approach to monitoring.

This micro management is unnecessary, not good for the call handler or client. For me these types of workplaces are the modern day sweatshop. Management is authoritarian, dispiriting and is just not creative. (Employee in Government Call Centre)

All too often performance is criticised but little is done to offer training to help improve employee performance and there is not much chance of challenging the supervisor's evaluation. (Call Centre Employee Service Sector)

Another participant explained how monitoring caused anxiety about how they performed their task. The respondent described how call centre operatives received feedback on the quality of call handling via call monitoring exercises and customer feedback. They felt that criticism seemed to be constant which was demoralising and the performance scores also had a likely impact on work allocation and pay. Several respondents who worked in call centres acknowledged some need for monitoring, and appreciated that it had some positive elements such as ensuring workers are focused, assessing productivity, and improving the quality of work. However, they also emphasised important negatives for employers to consider such as trust issues, that people might feel restricted and

\footnotetext{
${ }^{42}$ Niemeijer, Frederiks, Riphagen, Legemate, Eefsting\&Hertog (2010) at 1138.

${ }^{43}$ Woolrych, Sixmith, Mortenson, Robinovitch, Feldman (2013).
} 
less creative, de-motivated and leaving staff feeling that monitoring is too intrusive. It is evident that excessive monitoring can have a damaging effect on morale, lead to absenteeism, high employee turnover, and poorer organisational performance. The views expressed by the respondents in call centres revealed feelings of a lack of control and stress ignited by management monitoring.

\section{Sport Clubs}

Interviews with sports analysts, coaches and trainers at professional sports clubs revealed that monitoring of playing staff is a growing and important phenomenon. Players are subject to monitoring in respect of food, weight, strength, fitness and sleep. Player management software is used to provide data on players. In relation to this type of monitoring the players are aware of it and without exception in terms of those interviewed 'bought' into it in order to try and gain marginal advantages in relation to performance. An interesting dimension in relation to professional sport is the monitoring of training sessions. In particular, at some clubs this was done on a 'spot check' basis and so players were not informed but received a review of their training performance after the session had finished.

Players are very accepting of performance monitoring they understand it is important to improve performance and gain a competitive advantage despite the fact some of the data we capture is intrusive to their private life. (Cricket Coach)

In professional sport, monitoring linked to the game and performance is well accepted and established. However, that said you do have to be careful with some players that they do not feel 'got at' - otherwise it can cause a loss of confidence, motivation and undermine trust. You have to communicate the information to players as individuals. Some need a tough talking with; others need an arm around the shoulder and encouragement. (Cricket Coach)

The players see the monitoring they are subject to as linked to the work context and performance and hence relevant to the work environment. Remember we are not necessarily talking about highly paid sports stars, it covers lower league players as well. Essentially, it is accepted because of the work context. They are often young players keen to develop their ability, skills and learn. (Football Coach)

In the sporting context, respondents emphasised that monitoring of training not only provided a tool for the analysis of a training session, it also acted as a mechanism for improving communication between player and coach and helped identify any problems in relation to performance or injury at an early stage. In this respect Woolrychet al. ${ }^{44}$ emphasise the importance of recognising that monitoring can be 'transformative in nature"45 (2013, p8). Employees perceived the use of monitoring in the sports environment very differently than

\footnotetext{
${ }^{44}$ Woolrych, Sixmith, Mortenson, Robinovitch, Feldman (2013).

${ }^{45}$ Woolrych, Sixmith, Mortenson, Robinovitch, Feldman (2013) at 8.
} 
employees in call centres. In sport it was viewed as a tool to advance personal development and performance. In call centres employees regarded it as a vehicle for disciplinary action by management. The interviews revealed that the disparity was primarily due to the management approach in the respective sectors.

\section{(f) Monitoring Outside Work Hours}

A particularly controversial aspect of monitoring was covert surveillance outside work. The majority of respondent employees were against the practice completely. However, several respondents thought it might be justified in specific and exceptional circumstances.

\section{The operator of an investigation and surveillance business stated:}

We have seen a growth in cases where we are being asked to investigate cases of long-term absenteeism where employees are using that time to run or start their own businesses. (Private Detective)

However, many employees thought monitoring outside working hours was disproportionate and unjustified.

As a general rule I am against surveillance outside work unless there is a significant justification such as suspected fraud.

I can understand why employers engage in covert monitoring of social media although it does make me feel rather uncomfortable. As a general policy I do not think it should be done unless some kind of suspicion about an employee's behaviour has arisen.

However, what was evident from the interviews with employers was that covert monitoring of social media and checking of employee absence was relatively common. In this respect it would appear that a number of employers are not abiding by the Information Commissioners Code issued under the DPA 1998 which requires that covert monitoring should only be deployed where the criminal activity or equivalent malpractice is suspected. Furthermore, many employee respondents thought they had privacy rights in respect to covert social media monitoring that the law does not furnish them with. Employee respondents were hostile to the practices of covert monitoring outside work and the monitoring of social media accounts. Research by Zweig and Webster ${ }^{46}$ identified that employees viewed some types of monitoring as unfair and invasive and that this produced a psychological barrier to acceptance of the monitoring by employees. Whilst some workers could understand why an employer might want to engage in this, the legitimacy of it was felt to depend on motive. Respondents indicated that they did not think an employer should engage in 'fishing expeditions', randomly looking at workers' profiles to find something. It was evident that the majority of respondents believed that covert monitoring should only be used if a specific justification could be given for it and that it was targeted and limited. One respondent employee noted:

\footnotetext{
${ }^{46}$ Zweig \& Webster (2002).
} 
The problem with monitoring people at work is that it makes you feel as someone is watching you all the time. It makes people feel inhibited and less creative.

This comment demonstrates the 'chilling effect' surveillance can have. ${ }^{47}$ The fact one is being subject to monitoring can have a restricting effect on individual conduct and behaviour in the workplace. This might have the knock-on effect of the unintended consequence of undermining worker performance and creativity thus damaging the employer's business. Respondents reported that whilst some level of monitoring can make you more disciplined at work and contribute to improved work performance it was evident a delicate balance needed to be struck. Excessive monitoring can negatively affect performance, result in a lack of trust, demotivate staff and is not conducive to the creation of a positive work environment.

\section{(ii) Employees views on monitoring and how employees are informed of monitoring}

Employees are accepting of monitoring where it is fully explained to them, they are asked to provide consent, and it relates to the performance of their work. A few interviewees explained how monitoring that was too excessive alienated staff and damaged employer - employee relations.

I can see that monitoring might be justified in limited circumstances but completely disagree with illicit monitoring. If you want to improve employee behaviour the best way to achieve this is through education and training, not monitoring of activities.

I can see in certain circumstances monitoring can be useful for employees, for example in the police, if someone makes a false accusation. However, too extensive a monitoring is intrusive and not appropriate. Whether monitoring is reasonable depends on the setting and the circumstances. I think a general blanket policy is wrong.

Stoney and Tompkins ${ }^{48}$ argue that employee involvement in the design and implementation of monitoring systems may increase acceptance. This is reflected in the accounts of several respondents.

Our monitoring of email and computer use does not infringe on the privacy of employees since they have agreed to it in the contract of employment and information about monitoring is disseminated through company policies. [HR Manager Hi-Tech Firm]

When I arrived I was astonished that the company did not have a monitoring and surveillance policy. I drafted one, had it sent to all staff by email and asked each of them to confirm in writing that they had read and understood it.

\footnotetext{
${ }^{47}$ Oliver (2002).

${ }^{48}$ Stoney \& Tompkins (1997).
} 


\section{[HRM Manager]}

The majority of respondents believed workers should be informed of monitoring through a formal process and asked to consent to it. The view was that the policy should be written down and workers receive specific notification through the contract of employment. There was much greater acceptance of monitoring where it was communicated and explained to employees on recruitment and they were provided with a policy document. The guidelines usually covered both employer internal and external electronic facilities and access to the intranet generally. Policies also often referred to 'blogging' which was described as "the sharing of opinions and thoughts in an on-line diary". Employers often reserved the right to take disciplinary action should the contents of any blog, including pages on sites such as MySpace or Facebook "be found to lower the reputation of the organization, staff or customers and/or contravene the company's equal opportunities policy". In most cases employees were required to sign a document agreeing to "implement and abide by organization policy". Through the contract of employment and associated policies the employer is defining their right to monitor and therefore reduce employee expectation of privacy. ${ }^{49}$

The interviews revealed that whilst employees were often informed that monitoring was taking place they were not well versed about the extent of the monitoring. Several respondents were ambivalent about the fact monitoring was in operation, demonstrated little knowledge of the nature of monitoring and were indifferent as to whether the monitoring was legal or not. These categories of employees were more concerned with issues such as workload, job satisfaction and pay. Monitoring and surveillance featured low on their list of priorities.

\section{(iii) Employment Relations Context}

In the next section some employee relations implications arising from employer monitoring are discussed. First, policies were more comprehensive in the larger organisations within the sample and were enforced more strictly. For example, where breaches of rule occurred, the following system of disciplinary procedure was invoked: a) verbal warning; b) written warning; c) final writing warning; and d) dismissal. The presence of a formal written policy was largely absent in the smaller to mid-sized organisations. In these environments, there was a general belief that employees would develop an understanding of the expectations of the organisation and learn to act appropriately through day-today instruction and interaction.

Next, findings in relation to employer and employee attitudes to covert surveillance are considered. As stated earlier the majority of employee respondents conveyed the view that whilst monitoring within the work environment was acceptable, monitoring outside was not. However, there was a view that the boundary can be blurred in relation to the monitoring of social media. For example, one employee identified a case that arose where the company had monitored the social media account of a worker provided by a recruitment

\footnotetext{
${ }^{49}$ Dillon, Hamilton, Thomas, \&Usry (2008).
} 
agency because he had been making extravagant claims about his previous work experience. From social media monitoring the employer discovered that he had been previously convicted of fraud and that he was stealing company products and selling them privately. Information about the previous conviction had not been disclosed by the recruitment agency and without social media monitoring would not have been detected.

Furthermore, respondents raised substantive privacy concerns about social media screening by employers. There was a belief that it was not fair for an employer to be permitted to view pictures and comments that might have been made with no reasonable expectation that they would be used by an employer in recruiting or dismissal decisions. The law of privacy is important for employers to take into account at this stage. The employer needs to think carefully about whether their monitoring is reasonable, proportionate and legitimate. It is information that is on an objective basis relevant to the post or merely subjective that might result in unfair employment decisions being made. However, it should be noted that UK legal decisions have decided that entries a worker makes on social media can be used as evidence by an employer in disciplinary proceedings and that it might not constitute a breach of human rights for an employer to rely on this information ${ }^{50}$. Indeed, in this domain it might be relatively straightforward for an employer to argue that an employee's actions in posting comments on social media couldbreak the implied duty to maintain loyalty, fidelity and confidence. The majority of employee respondents expressed both surprise and concern when informed of the legal cases that endorsed the right of the employer to use entries on social media accounts to justify/defend unfair dismissal and breach of employment contract cases. The view was that the law as currently framed shifted the pendulum too much in favour of the employer interest and did not take sufficient account of employee freedom and privacy. Worker respondents expressed dismay that even where a person had privacy settings making comments only available to friends and this information was then subsequently passed on to an employer this information could still be validly used by an employer in disciplinary proceedings without the courts concluding an infringement of human rights privacy law has taken place. ${ }^{51}$

However, in Whitham v. Club $24^{52}$ the employer was found to have unfairly dismissed an employee for what the tribunal described as relatively mild remarks on social media and held that the dismissal fell outside the band of reasonable responses open to the employer in the circumstances. Furthermore, the tribunal gave employers some advice about social network monitoring. The tribunal observed that a company social media policy must be in place. Employees must be in no doubt as to the terms of the policy and the punishment that will ensue in the event of abreach. An employer must make it clear that it will be regarded as abreach of confidentiality and give clear examples of behaviour

\footnotetext{
${ }^{50}$ See Gill v SAS Ground Services UK Ltd(2009); Preece v JD Wetherspoons plc [2011]; Crisp v Apple Retail (UK) Ltd [2011]; Teggert v Tele Tech UK(2011); Otomewo v Carphone Warehouse Ltd [2012];Xpert (2013); BWB v Smith [2015]; Smith v Leeds United [2015].

${ }^{51}$ Crisp v Apple Retail UK Ltd [2011].

${ }^{52}$ Whitham v. Club 24[2010].
} 
that will be regarded as gross misconduct. If an employee has infringed on the policy, do not act hastily, investigate thoroughly and weigh up the possible consequences of the employee's actions. Were they just feeling fed up and merely letting off steam or do the comments cause actual damage to the reputation of your business?

An important employment relations' issue of concern arising from the study was the number of employers who did not inform employees of monitoring practices. The study revealed that forty-five percent of employers did not inform employees about aspects of monitoring including telephone monitoring. The ECHR has made it clear through case law, that the notions of 'private life' and 'correspondence' prima facie cover telephone calls from business premises for the purposes of Article 8 ECHR. In the absence of warnings that one's calls would be liable for monitoring, the employee had a reasonable expectation as to the privacy of calls made from a work telephone and the same expectation should apply in relation to an employee's email and internet usage. ${ }^{53}$ An interesting illustration of this is where a worker had their workplace searched and some of his belongings seized by the employer, it was held that the search amounted to an interference with the employee's 'private life'; the court found that the employee had a reasonable expectation of privacy in relation of personal possessions that he kept in his office. ${ }^{54} \mathrm{~A}$ high-profile legal case in the UK involved a female police officer that was subject to covert surveillance while on sick leave. The police force concerned admitted breaching the Data Protection Act and infringing the officer's right to respect for her family and private life under Article 8 of the Human Rights Act, 1998. The senior officer in the force responsible for the investigation was criticised by the judge for not seeming to have any appreciation or understanding of the laws that regulate employer conduct in this area. ${ }^{55}$ In this respect it might be useful for employers to pay attention to the Information Commissioners Code of practice relating to monitoring which provides that:

It will usually be intrusive to monitor your workers, workers have legitimate expectations that they can keep their personal lives private and that they are also entitled to a degree of privacy in the work environment, if employers wish to monitor their workers, they should be clear about the purpose and satisfied that the particular monitoring arrangement is justified by real benefits that will be delivered, workers should be aware of the nature, extent and reasons for any monitoring, unless (exceptionally) covert monitoring is justified, and in any event, workers' awareness will influence their expectations (Employment Practices Data Protection Code 2011).

Finally, in an employee relations context the study found inconsistencies in the way some breaches of rules were dealt with when they had been revealed by monitoring, with the rigorousness of investigation and the nature and extent

\footnotetext{
${ }^{53}$ Halford v UK [1997]; Copland v. United Kingdom [2007]; Barbulesc u v. Romania [2016] para 37.

${ }_{54}^{5}$ Peev v. Bulgaria [2007].

${ }^{55}$ Shaw (2016).
} 
of sanctions being dictated by (a) management attitude, (b) the nature of the role the employee held (perceived star performers were dealt more leniently than other workers) (c) the degree of importance the organisation attached to the particular breach, (d) the importance placed on health and safety regulations which were revealed to have been breached by monitoring. Inconsistencies in the treatment of individuals for breaches of the rule were problematic resulting in disgruntled and demotivated staff. Some study respondents expressed the view that interpreting the rules differently and not applying the same sanctions undermined the authority of management and represented an example of poor employee relations practice.

\section{Conclusion}

This study has examined the ways in which monitoring methods are deployed within organisations and employer and employee perceptions of such monitoring. It is evident from the interviews that monitoring represents an important element of protecting organisational interests. A recurrent message that was highlighted by participating managers and employees was that employers had a legitimate right to protect assets, ensure the efficient performance of the organisation and maintain health and safety in the workplace. The findings also suggest that organisational monitoring can indeed have a positive influence in shaping employee attitudes and behaviour. In particular, monitoring can be deployed as a useful mechanism for protecting staff from false accusations when carrying out their work and protecting them from discrimination or harassment. However, several respondents described how they felt monitoring demonstrated a lack of trust and loyalty by the employer. While certain monitoring practices might appear reasonable or required by law in so far as they concern the health and safety of workers, the study reveals a number of monitoring practices might lead to unfair or discriminatory employment decisions being made. Furthermore, the inconsistent application of such policies can have negative implications for employee work experiences and result in employees questioning the fairness of the treatment they are subject to within organisations. Information and consultation with employees or employee representatives relating to monitoring might develop a more constructive relationship and also elicit views from employees, helping develop a more transparent, fairer and tolerant workplace context. Indeed, the study revealed that information sharing and consultation with staff associations and/or trade unions in relation to monitoring had the effect of producing a new spirit of openness and improved employee relations. In some instances managers also benefitted from relevant training to increase their confidence in addressing sensitive, monitoring issues at work. The flow of information between employers and employees in relation to monitoring is of particular importance in a rapidly changing technological and workplace environment. A proper flow of information is fundamental to good relations and a positive partnership between employer and employee. ${ }^{56}$ It is

\footnotetext{
${ }^{56}$ Gospel \& Lockwood (1999),
} 
important for organisations to be sensitive to the fact that as an employer it must ensure that it strikes a fair balance between an employee's right to privacy and the employers' legitimate business interests. ${ }^{57}$

The responses from the study demonstrated some divergence in the views of both employers and employees alike about monitoring that reflects the major ideological arguments that dominate the literature. ${ }^{58}$ Some view monitoring as coercive control whereby an employer can expose and coerce untrustworthy employees. ${ }^{59}$ Another perspective is to regard surveillance as a means to prevent crime and fraud. ${ }^{60}$ Others see surveillance as a form of caring to protect employees from unfair treatment. ${ }^{61}$ Finally, there are those who regard workplace monitoring as an infringement of employees' rights to privacy. ${ }^{62}$

Employee and employer perceptions of what constitutes reasonable and unreasonable monitoring seem to be constantly evolving along with the technology that can be utilised to engage in monitoring activities. There is an emerging consensus amongst employees that good surveillance is targeted and dependent on the work context. However, many employers who engage in monitoring seem to incrementally expand it to new areas of the workplace. In this respect the findings reflect the observation of Findlay and McKinlay $^{63}$, that insufficient attention is given by surveillance theory to asking what purpose, if any, monitoring, recording and archiving data may serve. This study has also raised some concerns that a large number of employers are not complying with the Information Commissioners' Code on monitoring. To date this does not appear to have resulted in large numbers of complaints by employees but it does leave organisations susceptible to legal challenge. However, as technology develops and employer demand for information on worker performance increases, human resource management practices and legal issues might become more prominent and problems more prevalent.

\section{References}

Allen, M.W., Walker, K.L., Coopman, S.J. and J.L. Hart (2007). 'Workplace Surveillance and Managing Privacy Boundaries'. Management Communication Quarterly 21(2): 172-200.

American Management Association (2001).2001 survey on workplace monitoring and surveillance. Available from www.amnet.org

Ariel, B. (2016). 'Body-Worn Cameras Cause a Reduction of More Than 90\% in Complaints against Police Officers. In View: Commentary from BWC Experts.

\footnotetext{
${ }^{57}$ Dillon, Hamilton, Thomas \& Usry (2008).

${ }^{58}$ Barry, Fiedman \& Reed (2007); Allen, Walker, Coopman \& Hart (2007); Sewell \& Barker (2006).

${ }^{59}$ Sewell \& Barker (2006).

${ }^{60}$ Findlay and McKinlay, 2003).

${ }^{61}$ Findlay \& McKinlay(2003): Miller \&Weckert (2000); Sewell \& Barker (2006); Mason,

Button, Lankshear, Coates \& Sharrock (2002).

${ }^{62}$ Findlay \& McKinlay (2003); Levy (1994).

${ }^{63}$ Findlay \& McKinlay (2003).
} 
Body Worn Cameras Training \& Technical Assistance.' [http://bwctta.com/resou $\mathrm{r}$ ces/commentary/view-commentary-bwc-experts-1]

Ball, K. (2010). 'Data protection in the outsourced call centre: an exploratory case study'. Human Resource Management Journal 20(3): 294-310.

Barry, A., Fiedman, L. \& J. Reed (2007).'Workplace Privacy: Employee Relations and Legal Implications of Monitoring Employee E-mail Use'. Employee Responsibilities and Rights Journal 19: 75-83.

Ben Mortenson, W. Sixsmith, A. \& R. Woolrych (2015). 'The powers of observation: theretical perspectives on surveillance technologies and older people'. Ageing \& Society 35(3): 512-530. Published online 2013doi: 10.1017/S0144686X13000846.

Botan, C. (1996). 'Communication work and electronic surveillance: A model for predicting panoptic effects'. Communication Monographs 63(4); 293-313.

Boyd, C. (2002). 'Customer violence and employee health and safety'. Work Employment and Society 16(1): 151-169.

Brown, V.R. \& E.D. Vaughan (2011). 'The writing on the (Facebook) wall: the use of social networking sites in hiring decisions'. Journal of Business and Psychology 26: 219-225.

Brown, W.S. (2000). 'Ontological Security, Existential Anxiety and Workplace Privacy'. Journal of Business Ethics 23: 61-65.

Chature, M. (2010). 'Privacy in the workplace'. World Intellectual Property Review, May/June, 42-43, www.worldpreview.com

Coleman, C. (2016). Metropolitan Police to pay damages over holidaying officer probe. BBC News24 August 2016. http://www.bbc.co.uk/news/uk-37167741

D’Urso, S.C. (2006). 'Who's watching us at work? Toward a structural-perceptual model of electronic monitoring and surveillance in organizations'. Communication Theory 16: 281-303.

Deery, S., Walsh, J., \& D. Guest (2011). 'Workplace aggression: the effects of harassment on job burnout and turnover intentions'. Work, employment and Society. 25(4): 742-759.

Dillon, T.W., Hamilton, A.J., Thomas, D.S. \& M.L. Usry (2008). 'The Importance of Communicating Workplace Privacy Policies'.Employee Rights and Responsibilities Journal 20: 119-139.

Employment Practices Data Protection Code (2011). Information Commissioner, Wilmslow, England.

Esen, E. (2005). SHRM Research, Workplace privacy poll findings, Alexandria, VA: Society for Human Resource Management.

Findlay, P. \& A. McKinlay (2003). 'Surveillance, electronic communications technology and regulation'. Industrial Relations Journal 34: 305-318.

Ford, M. (2002). 'Two conceptions of worker privacy'. Industrial Law Journal 31(2): 2 $135-155$.

Foucalt, M. (1979). Power, Truth Strategy (ed. Morris M and Patton P). Sydney, NSW, Australia: Feral Publications.

Gospel, H. \& G. Lockwood (1999). 'Disclosure of Information for Collective Bargaining: the CAC Approach Revisited'. Industrial Law Journal 28(3): 233-248.

Grandey, A., Dickter, D., \& H. Sin (2004). 'The customer is not always right: customer aggression and emotion regulation of service employees'. Journal of Organizational Behaviour 25(3): 397-418.

Hunt, C., Davidson, M., Fielden, S. \& H.Hoel (2007). 'Sexual Harassment in the Workplace: A Literature Review', Equal Opportunities Commission Working Paper Series no. 59. UK: Manchester. 
Jeske, D. \&K. Shultz(2016). 'Using social media content for screening in recruitment and selection: pros and con's'. Work, employment and society 30(3): 535-546..

King, N. (2004). 'Using Interviews in Qualitative Research'. In: C. Cassell \& G. Symon (eds) Essential Guide to Qualitative Methods in Organisational Research, 11-23. London: Sage.

King, N.J. (2003). 'Electronic Monitoring to Promote National Security Impacts Workplace Privacy'. Employee Responsibilities and Rights Journal 15(3): 127147.

Lee, S. \& B.H. Kleiner (2003).'Electronic surveillance in the workplace'. Management Research News 26:72-81.

Levy, M. (1994). The electronic monitoring of workers: Privacy in the age of the electronic sweatshop. Legal Reference Services Quarterly 14 (3):5-56.

Mason, D., Button, G., Lankshear, G., Coates, S. \& W. Sharrock (2002). 'On the poverty of apriorism: Technology, surveillance in the workplace and employee responses'. Information, Communication and Society 5: 555-572.

Mello, J.A. (2003). 'The evolving nature of the employment relationship: Reconsidering employee responsibilities and rights'. Employee Responsibilities and Rights Journal 15: 99-101.

Miller, S. \& J. Weckert (2000). 'Privacy, the workplace and the Internet'. Journal of Business Ethics 28: 255-265.

Nath, V. (2011). 'Aesthetic and emotional labour through stigma: national identity management and racial abuse in offshored Indian call centres'.Work, employment and Society 25(4): 709-725.

National Workplace Institute (2004). Report privacy under siege: Electronic monitoring in the workplace.

Niemeijer, A.R., Frederiks, B.J.M., Riphagen, I.I., Legemaate, J., Eefsting, J.A. \&, C.M.P.M. Hertogh (2010). 'Ethical and practical concerns of surveillance technologies in residential care for people with dementia or intellectual disabilities: an overview of the literature'.International Psychogeriatrics 22(7): 1129-1142

Nord, G.D., McCubbins, T.F. \& J.H. Nord (2006).'E-Monitoring in the Workplace: Privacy, Legislation, and Surveillance Software'. Communications of the ACM 49(8): 73-77.

Oliver, H. (2002). 'Email and internet monitoring in the workplace: information privacy and contracting-out'. Industrial Law Journal 31: 321-352.

Patton, M.Q. (1990).Qualitative Evaluation and Research Methods. Newbury Park, CA: Sage.

Phillips, G., and K. Scott (2016).Employment Law, College of Law Publishing, Legal Practice Guides, London.

Practical Law (1997). Libel by e-mail, Norwich Union Pays the Price. Thompson Reuters.

Sewell, G. \& J.R. Barker (2006). 'Coercion versus care: Using irony to make sense of organizational surveillance'. Academy of Management Review 31(4): 934 - 961.

Sewell, G., Barker, J.R. \& D. Nyberg (2012). 'Working under intensive surveillance: When does 'measuring everything that moves' become intolerable'. Human Relations 65(2): 189-215.

Shaw, D. (2016). Police body cameras 'cut complaints against officers'. BBC News 29 September 2016.http://www.bbc.co.uk/news/uk-37502136

Smith, M.J., Carayon, P., Sanders, K.J., Lim, S.Y. \& D. LeGrande (1992). 'Employee stress and health complaints in jobs with and without electronic monitoring'. Applied Ergonomics 23(1): 17-27.

Social Care Institute for Excellence (2014). 'Electronic Surveillance in health and Social Care Settings: a brief review', SCIE, London. 
Stahl, B.C. (2008). 'The Impact of the UK Human Rights Act 1998 on Privacy Protection in the Workplace'.IGE Global 50-62.

Stoney, A.G. \& P.K.Tompkins (1997). 'Electronic Performance Monitoring: An organizational Justice and concretive control perspective'. Management Communication Quarterly 10(3): 259-289.

Taylor, S. \& A. Emir (2015).Employment Law - an Introduction. $4^{\text {th }}$ ed. Oxford: Oxford University Press.

Taylor, S. \& M. Tyler (2000). 'Emotional labour and sexual difference in the airline industry'. Work, Employment and Society 14(1): 77-95.

Thomas, S.L., Rothschild, P.C. \& C. Donegam (2014). Social networking, management responsibilities, and employee rights: the evolving role of social networking in employment decisions. Employee Responsibilities and Rights Journal 27(4): 307323.

Timming, A.R. (2015). 'Visible tattoos in the service sector: a new challenge to recruitment and selection'. Work, Employment and Society 29(1): 60-78.

Van Iddekinge, C.H., Lanivich, S.E., Roth P.L. \& E. Junco (2016). 'Social media for selection? Validity and adverse impact potential of a Facebook-based assessment'. Journal of Management 42(7): 1811-1835.First published online: December 16, 2013 https://doi.org/10.1177/0149206313515524

Warhurst, C. \& D.Nickson (2007). 'Employee experience of aesthetic labour in retail and hospitality'. Work, Employment and Society 21(1): 103-20.

Waugh, R. (2012). 'They're watching you! By 2015, 60 per cent of employers will monitor their worker's Facebook pages'. Mail Online, 1 June 2012.

Westin, F. (1996). 'Privacy in the Workplace: How well does American Law Reflect American Values?'.Chicago-Kent Law Review72: 271-283.

Winstanley, D. (2000).'The ethical dimension of human resource management'. Human Resource Management Journal 10: 2, 5-20.

Woolrych R., Sixsmith A., Mortenson B., Robinovitch S. and F. Feldman (2013). 'The nature and use of surveillance technologies in residential care'. In: J. Biswas, H. Kobayashi, L. Wong L., B. Abdulrazak \& M. Mokhtari (eds.): Inclusive Society: Health and Wellbeing in the Community, and Care at Home: 11th International Conference on Smart Homes and Health Telematics, ICOST 2013, Singapore. Proceedings; Springer Berlin Heidelberg, Germany.

Xpert HR., (2013) Tribunal Watch. Social media: 10 employment cases involving Facebook. Xpert HR.

Yagil, D. (2008).'When the customer is wrong: a review of research on aggression and sexual harassment in service encounters'. Aggression and Violent Behaviour 13(2): 141-152.

Zweig, D. \& K. Scott (2007).'When unfairness matters most: supervisory violations'. Human Resource Management Journal 17(3): 227-247.

Zweig, D. \& J. Webster (2002). 'Where is the line between benign and invasive? An examination of psychological barriers to the acceptance of awareness monitoring systems'. Journal of Organisational Behaviour 23(5): 605-633. 
Vol. 4, No. 3 Lockwood: Workplace Monitoring and Surveillance: The British Context

\section{Legislaton}

Human Rights Act, 1998.

Data Protection Act, 1998.

Employment Practices Data Protection Code, 2011.

Regulation of Investigatory Powers Act, 2000

Telecommunications (Lawful Business Practice) (Interception of Communications)

Regulations, 2000

Equality Act, 2010

General Data Protection Regulation, European Union Regulation, 2016/679 (GDPR)

\section{Cases}

Babulescu v. Romania [2016] ECHR

$B W B v$ Smith [2015] UKEATS/0004/15

Copland v. United Kingdom[2007] ECHR 253

Crisp v Apple Retail (UK) [2011] ET 1500258/11

Garamukanwa v Solent NHS Trust [2016] UKEAT/0245/15/DA

Durant v. Financial Services Authority[2004] EWCA Civ 1746

Gill v SAS Ground Services UK Limited (2009) ET/2705021/09

Halford $v$ United Kingdom [1997] IRLR471

Otomewo v Carphone Warehouse Ltd (2012) ET/2330554/2011

Peev v. Bulgaria [2007] 6409101ECtHR

Preece v J.D. Weatherspoons Plc [2011] ET/2104806/10

Smith v Trafford Housing Association [2012] EWHC 322 (CH) HC

Smith v Leeds United [2015] ET/180645/15

Stephens v Halfords Plc [2010] ET/1700796/10

Teggart $v$ Tele Tech UK Ltd [20121]ET/N11T/704/11

United Bank v. Akhtar [1989] IRLR 507

Witham v Club 24 Ltd ET [2010] 18/0462/10 